\section{Behavioural and virological studies on a rescued Oriental White-backed Vulture Gyps bengalensis from western Maharashtra, India}

\author{
Satish Pande ${ }^{1}$, Pranav Pandit ${ }^{2}$, Aditya Ponkshe ${ }^{3}$, \\ Ram Mone ${ }^{4}$, Shailesh Pawar ${ }^{5}$ \& Akhilesh Mishra ${ }^{6}$ \\ ${ }^{1-4}$ Ela Foundation, C-9, Bhosale Park, Sahakarnagar-2, Pune, \\ Maharashtra 411009, India \\ ${ }^{5,6}$ National Institute of Virology, Microbial Containment Complex, \\ 130/1, Sus Road, Pashan, Pune, Maharashtra 411021, India \\ Email: ${ }^{1}$ pande.satish@gmail.com, ${ }^{2}$ pranav.vet@gmail.com, \\ ${ }^{3}$ ponkshe.aditya@gmail.com, ${ }^{4}$ moneram@gmail.com, \\ ${ }^{5}$ pawarshailesh@hotmail.com (corresponding author), \\ 6acm1750@gmail.com
}

On 05 August 2008 a villager witnessed a large raptorial bird descending from the sky and landing on the ground, in an open field at Bhangaon Village, Shrigonda Taluk (18 $\left.61^{\prime} \mathrm{N} \& 7^{\circ} 69^{\prime} \mathrm{E}\right)$, Pune District, Maharashtra, India. The bird looked exhausted and was unable to fly. When approached it assumed a drooping neck posture. The raptor was caught and was handed over to the forest department at Shrigonda. This is a semi-arid region on the Deccan Plateau interspersed with agricultural cropland, scrub areas and villages. This bird was identified as the Critically Endangered Oriental White-backed Vulture Gyps bengalensis.

Date of publication (online): 26 January 2011

Date of publication (print): 26 January 2011

ISSN 0974-7907 (online) | 0974-7893 (print)

Editor: William Dundon

\section{Manuscript details:}

Ms \# 02471

Received 28 May 2010

Final received 20 December 2010

Finally accepted 25 December 2010

Citation: Pande, S., P. Pandit, A. Ponkshe, R. Mone, S. Pawar \& A Mishra (2011). Behavioural and virological studies on a rescued Oriental White-backed Vulture Gyps bengalensis from western Maharashtra, India Journal of Threatened Taxa 3(1): 1490-1492.

Copyright: ( Satish Pande, Pranav Pandit, Aditya Ponkshe, Ram Mone Shailesh Pawar \& Akhilesh Mishra 2011. Creative Commons Attribution 3.0 Unported License. JoTT allows unrestricted use of this article in any medium for non-profit purposes, reproduction and distribution by providing adequate credit to the authors and the source of publication.

Acknowledgements: We are grateful to the Forest Department Maharashtra, for inviting us for the examination of the vulture, for local hospitality and for the necessary permissions. Mr. Prashant Deshpande, Ela Foundation for support in field work and staff of the Avian Influenza department for the laboratory assistance.

OPEN ACCESS | FREE DOWNLOAD
The vulture was kept in a nursery and offered $500 \mathrm{~g}$ of fresh raw beef daily. After an unsuccessful

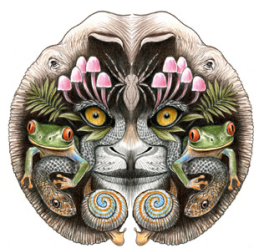
release attempt after five days in the nursery, it was kept in captivity for another week.

It has been reported that two species of vultures, the Indian White-backed Vulture and the Long-billed Vulture Gyps indicus, have declined in population by more than 90\% throughout India (Green et al. 2004; Shultz et al. 2004). Affected birds exhibit signs of illness (neck drooping syndrome) for approximately 30 days prior to death (Cunningham et al. 2003; Watson et al. 2008). Epidemiological observations have been found to be consistent with an infectious cause for this morbidity and mortality (Cunningham et al. 2003). We undertook further investigations on this bird because vultures are threatened with extinction and, therefore, it is of the utmost importance to investigate the causes of morbidity and mortality in these birds. With the permission of the forest department, samples for laboratory tests including haematology and virological studies were collected. The samples collected were blood, serum, cloacal and tracheal swabs. Virological investigations were performed at the National Institute of Virology (NIV), Pune, India. Fresh faecal samples were also examined for parasites and the bird was closely checked for the presence of ectoparasites. During this time the vulture, although active (e.g. flapping its wings often), appeared to be emaciated.

When the vulture was observed from outside of the room in which it was being nursed, it perched erect with its neck extended, alertly scrutinizing its surroundings. However, when the vulture was approached by entering the room, it adopted a posture indicative of thanatosis, a behaviour of birds in which they exhibit neck drooping and feign death (Watson et al. 2008). When touched, the vulture gave the typical threat display of extended wings, flared body feathers, jabbed with its powerful beak and lashed out with one foot in a threatening manner. Upon retreating, the neck drooping posture was not resumed and the wings were kept extended for some time.

The biometry and haematological findings of the captive individual were as shown in Table 1. Blood parasites including Plasmodium species were specifically looked for because they have been described as one of the causes of morbidity in vultures 
Table 1. Biometry and haematology of the Indian Whitebacked Vulture Gyps bengalensis.

\begin{tabular}{|c|c|c|}
\hline Parameter & Observed value & Range \\
\hline Wing chord & $610 \mathrm{~mm}$ & $535-608$ \\
\hline Tail & $290 \mathrm{~mm}$ & $217-232$ \\
\hline Tarsus & $109 \mathrm{~mm}$ & $108-124$ \\
\hline Beak length & $68 \mathrm{~mm}$ & $71-81$ \\
\hline Beak depth & $35 \mathrm{~mm}$ & - \\
\hline Middle toe & $94 \mathrm{~mm}$ & - \\
\hline Talon & $24 \mathrm{~mm}$ & - \\
\hline Weight & $2850 \mathrm{~g}$ & $\begin{array}{l}3500-5560 \mathrm{~g} \\
(\mathrm{n}=29 \text { males } \\
\text { and females) }\end{array}$ \\
\hline Total erythrocyte count & $2.0 \times 10^{6} / \mathrm{mm}^{3}$ & - \\
\hline Total leucocyte count & $14.6 \times 10^{6} / \mathrm{mm}^{3}$ & $<10^{9} / \mathrm{mm}^{3}$ \\
\hline Haemoglobin & $8 \mathrm{~g} / \mathrm{dl}$ & $12.2-20 \mathrm{~g} / \mathrm{dl}$ \\
\hline
\end{tabular}

(Ranges for biometry parameters are as per Ali \& Ripley 1969; ranges for haematological parameters are as per Coles 1997)

(Sudhan et al. 2004). Parasites were not seen in the blood smear.

India experienced several outbreaks of highly pathogenic avian influenza (HPAI) H5N1 in domestic poultry from 2006 to 2009 in parts of the western and northeastern states; namely Maharashtra and Gujarat, Madhya Pradesh, West Bengal, Assam and Tripura (Chakrabarti et al. 2009). Avian influenza (AI) surveillance in wild migratory, wild resident, domestic birds and poultry was undertaken by the NIV jointly with the Ela Foundation, Pune, India from 2006 to 2008 and various bird samples were screened for HPAI H5N1 and other AI viruses (Pawar et al. 2009). To rule out the possibility of infection with AI viruses and other viral infections, cloacal, tracheal and serum samples were collected from the vulture. The cloacal and tracheal samples were transported in viral transport medium (Hank's balanced salt solution) with antibiotics (Penicillin, Streptomycin, Gentamycin, Amphotericin B) (WHO 2002). All of the samples were transported to the laboratory by cold-chain.

Cloacal and tracheal samples of the vulture were negative for AI viruses, Newcastle Disease Virus (NDV), Infectious Bursal Disease Virus by virus isolation. Serum was negative for the presence of antibodies against AI H5N1, H5N2, H9N2, H7N1, and NDV by the haemagglutination inhibition test. The ectoparasites found included a few unidentified bird lice.
The vulture was ringed and it gained $1.5 \mathrm{~kg}$ during the captivity period. There were no signs of bone injury or soft tissue trauma. On 24 July 2008, when a guard opened the door to feed the vulture, it escaped and flew away.

Two days later, at about $0630 \mathrm{hr}$, a farmer reported sparking followed by the sound of an explosion from overhead live electricity wires. He found a large dead bird on the ground underneath the wires, partially burnt and still smoking. He noticed the ring on the leg of the bird and contacted us. The location of the bird was Parner, Maharashtra about $60 \mathrm{~km}$ from the point of release. Subsequent necropsy revealed ecchymosis on the pectoral muscles. As there was no evidence to suggest visceral gout diclofenac estimations were not performed.

The neck-drooping behaviour, that the vulture had intermittently exhibited in captivity, was previously thought to be a sign of illness but it is now thought to be a mechanism of thermoregulation as well as a predator avoiding strategy especially when in close proximity to humans (Watson et al. 2008). We suggest that the neck-drooping behaviour observed by us could have been due to a predator avoidance strategy and not due to visceral gout. Neck-drooping has been previously associated with visceral gout which is caused by the ingestion of the drugs Diclofenac and Ketoprofen used to treat domestic livestock (Cunningham et al. 2003). We feel that such neck drooping is exhibited when a solitary vulture is approached by humans but, while feeding in flocks, this behaviour is not usually exhibited, even when humans approach. Vultures in flocks either ignore human presence or make threatening displays by sudden wing flapping and neck extension or they fly away for some distance if approached. We have observed such flock behaviour on innumerable occasions over the past 25 years (Pande et al. 2003). To summarize, no viral infection or toxicity was responsible for the morbidity observed in the vulture under investigation. The neck drooping behaviour reported here and which has previously been observed by others, was interpreted, in this context, as a predator avoiding strategy and, therefore, not due to illness. In addition, our report suggests that electrocution may also be an explanation for the decreasing numbers of vultures in India. 


\section{REFERENCES}

Ali, S. \& D.S. Ripley (1969). Handbook of the Birds of India and Pakistan together with those of Bangladesh, Nepal, Bhutan and Sri Lanka - Vol. 1. Oxford University Press, New Delhi, 384pp.

Chakrabarti, A.K., S.D. Pawar, S.S. Cherian, S.S. Koratkar, S.M. Jadhav, B. Pal, S. Raut, V. Thite, S.S. Kode, S.S. Keng, B.J. Payyapilly, J. Mullick \& A.C. Mishra (2009). Characterization of the Influenza A H5N1 Viruses of the 2008-09 Outbreaks in India Reveals a Third Introduction and Possible Endemicity. PLoS ONE 11: e7846.

Coles, B.H. (1997). Avian Medicine and Surgery. Blackwell Science, Second Edition, Cambridge, UK, 408pp.

Cunningham, A.A., V. Prakash, D. Pain, G.R. Ghalsasi, G.A.H. Wells, G.N. Kolte, P. Nighot, M.S. Goudar, S. Kshirsagar \& A. Rahmani (2003). Indian vultures: victims of an infectious disease epidemic? Animal Conservation 6: 189-197.

Green, R.E., I. Newton, S. Shultz, A.A. Cunningham, M. Gilbert, D.J. Pain \& V. Prakash (2004). Diclofenac poisoning as a cause of vulture population declines across the Indian subcontinent. Journal of Applied Ecology 41: 793-800.

Pande, S., S. Tambe, C.F. Francis \& N. Sant (2003). Birds of Western Ghats, Kokan and Malabar (including Birds of Goa), Oxford University Press, Mumbai, i-xii+377pp.
Pawar, S.D, S. Pande, A. Jamgaonkar, S. Koratkar, B. Pal, S. Raut, M. Nanaware, K. Ray, A. Chakrabarti, S.S. Kode, V. Thite, M.R. Khude, S. Randive, A. Basu, A. Pawashe, A. Ponkshe, P. Pandit \& P. Deshpande (2009). Avian influenza surveillance in wild migratory, resident, domestic birds and in poultry in Maharashtra and Manipur, India, during avian migratory season 2006-2007. Current Science 97: 550-554.

Shultz, S., H.S. Baral, S. Charman, A.A. Cunningham, D. Das, G.R. Ghalsasi, M.S. Goudar, R.E. Green, A. Jones, P. Nighot, D.J. Pain \& V. Prakash (2004). Diclofenac poisoning is widespread in declining vulture populations across the Indian subcontinent. Proceedings of the Royal Society B 271: S458-S460.

Sudhan, N.A., K.K. Ponuswamy, K. Husain \& M. Zama (2004). Anaemia in a Cinereus Vulture Aegypius monachus-A Case Report. Zoos' Print Journal (19)12: 1711.

Watson, R.T., M. Gilbert \& M. Virani (2008). Neckdrooping posture of Oriental White-backed Vulture (Gypa bengalensis) in close proximity to human observers. Journal of Raptor Research 42: 66-67.

WHO (2002). Manual on Animal influenza diagnosis and surveillance, WHO/CDS/CSR/NCS 2002. 5. 